\title{
Assessment of the Safety of U.S. Nuclear Weapons and Related Nuclear Test Requirements: A Post-Bush Initiative Update
}

R. E. Kidder

December 10, 1991

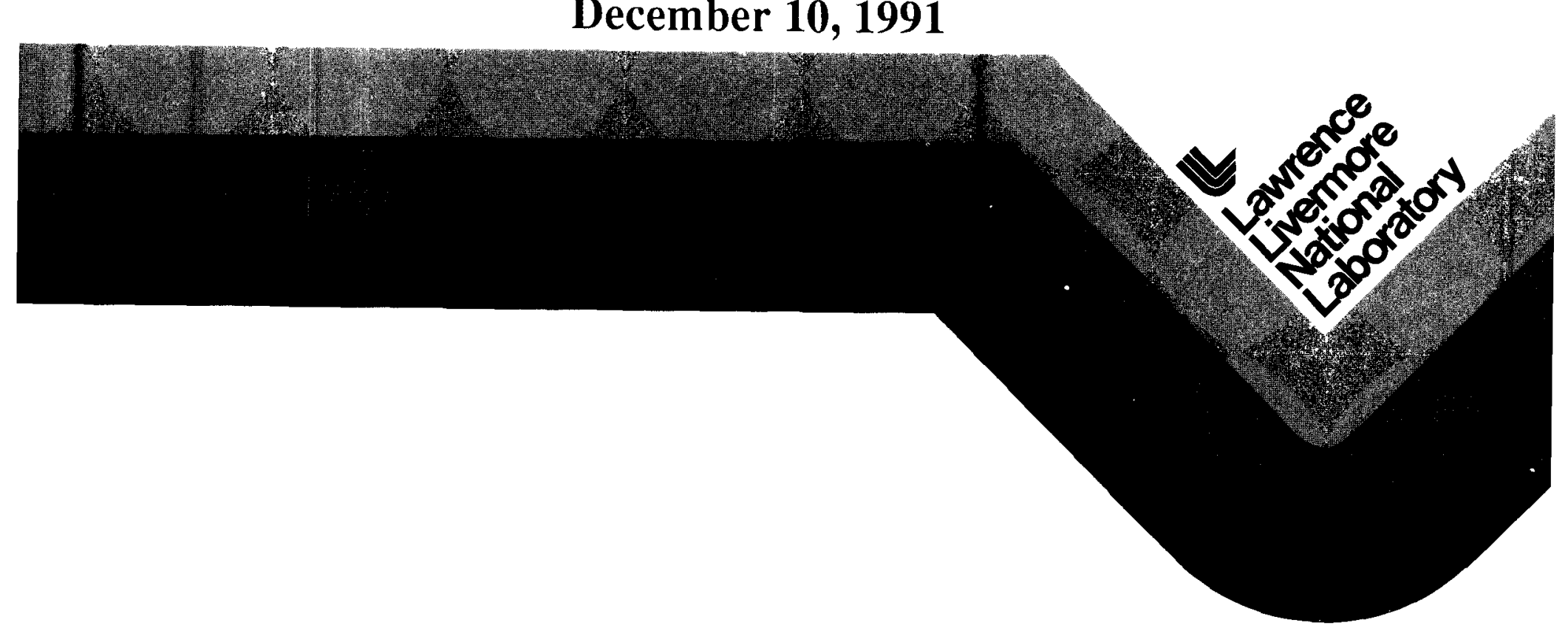




\title{
DISCLAIMER
}

This document was prepared as an acccount of work sponsored by an agency of the United States Government Neither the United States Government nor the University of California nor any of their employees, makes any warranty, express or implied, or assumes any legal liability or responsibility for the accuracy, completeness, or usefulness of any information, apparatus, product, or process disclosed, or represents that its use would not infringe privately own rights Reference herein to any specific commercial products, process, or service by trade name, trademark, manufacturer, or otherwise, does not necessarly constitute or imply its endorsement, recommendation, or favoring by the United States Government or the University of California The views and opinions of authors expressed herem do not necessarly state or reflect those of the United States Government or the University of California, and shall not be used for advertising or product endorsement purposes

\author{
This report has been reproduced \\ directly from the best avaliable copy \\ Avarlable to DOE and DOE contractors from the \\ Office of Scientific and Technical Information \\ PO Box 62, Oak Ridge, TN 37831 \\ Prices available from (615) 576-8401, FTS 626-8401
}

Avalable to the public from the

National Technical Information Service

US Department of Commerce

5285 Port Royal Rd.

Sprungfield, VA 22161

Work performed under the auspices of the US Department of Energy by Lawrence Livermore National Laboratory under Contract W-7405-Eng-48 


\section{DISCLAIMER}

This report was prepared as an account of work sponsored by an agency of the United States Government. Neither the United States Government nor any agency Thereof, nor any of their employees, makes any warranty, express or implied, or assumes any legal liability or responsibility for the accuracy, completeness, or usefulness of any information, apparatus, product, or process disclosed, or represents that its use would not infringe privately owned rights. Reference herein to any specific commercial product, process, or service by trade name, trademark, manufacturer, or otherwise does not necessarily constitute or imply its endorsement, recommendation, or favoring by the United States Government or any agency thereof. The views and opinions of authors expressed herein do not necessarily state or reflect those of the United States Government or any agency thereof. 


\section{DISCLAIMER}

Portions of this document may be illegible in electronic image products. Images are produced from the best available original document. 
UCRL-LR-109503

Distribution Category UC-700

UCRL-LR--109503

\title{
Assessment of the Safety of U.S. DE92 009767 Nuclear Weapons and Related \\ Nuclear Test Requirements: \\ A Post-Bush Initiative Update*
}

\author{
R.E. Kidder
}

December 10, 1991

*The views and opmons of the author expressed herem do not necessarnly state or reflect those of the Department of Energy, the University of Calıforna, or the Lawrence Livermore National Laboratory

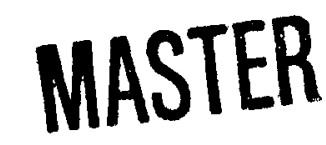





\section{Contents}

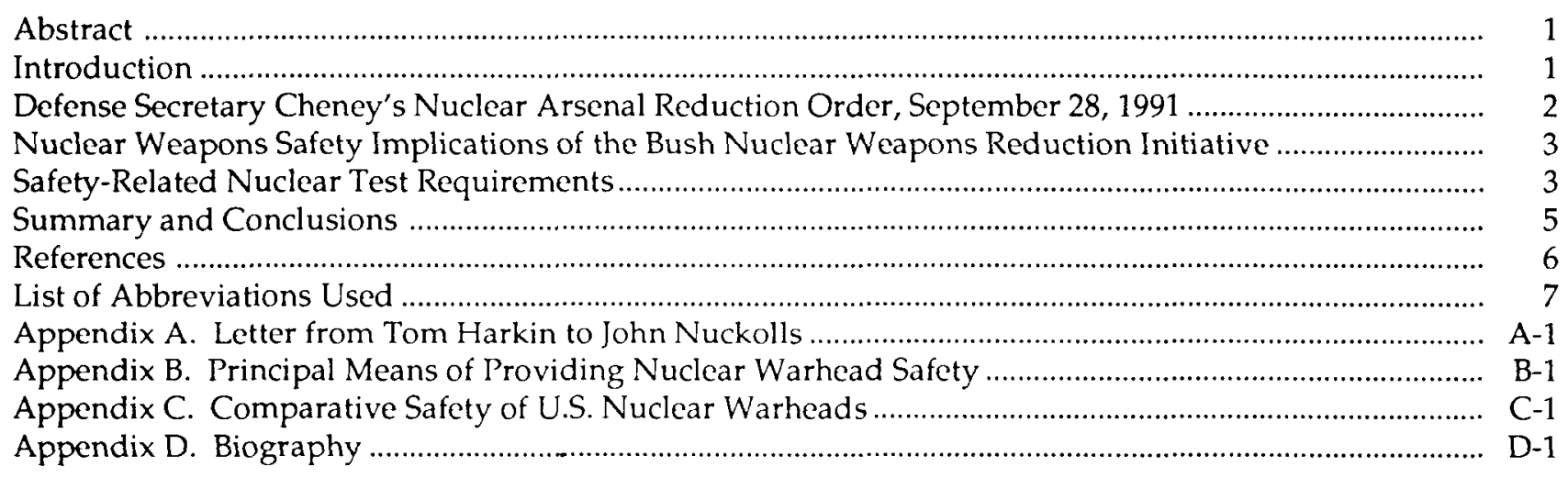




\title{
Assessment of the Safety of U.S. Nuclear Weapons and Related Nuclear Test Requirements: A Post-Bush Initiative Update
}

\begin{abstract}
The Nuclear Weapons Reduction Initiative announced by President Bush on September 27, 1991, is described herein as set forth in Defense Secretary Cheney's Nuclear Arsenal Reduction Order issued September 28,1991 . The implications of the Bush Initiative for improved nuclear weapons safety are assessed in response to a request by U.S. Senators Harkin, Kennedy, and Wirth to the Lawrence Livermore National Laboratory that the author prepare such an assessment.

The author provides an estimate of the number of nuclear tests needed to accomplish a variety of specified warhead safety upgrades, then uses the results of this estimate to answer three questions posed by the Senators. These questions concern pit reuse and the number of nuclear tests needed for specified safety upgrades of those ballistic missiles not scheduled for retirement, namely the Minuteman III, C4, and D5 missiles.
\end{abstract}

\section{Introduction}

Pursuant to a request by several members of the United States Senate and House of Representatives in November 1990, the author prepared an assessment of the safety of U.S. nuclear weapons. In this assessment, the author estimated that 10 to 20 nuclear explosive tests would be required to bring the remainder of the nuclear weapons stockpile up to modern safety standards, given already-scheduled retirements of older nuclear weapons. The unclassified version of this assessment was issued July 26, 1991, as Report to Congress: Assessment of the Safety of U.S. Nuclear Weapons and Related Nuclear Test Requirements. ${ }^{1}$

Two months later, on September 27, 1991, President Bush announced a sweeping new series of unilateral cutbacks in American nuclear defenses. ${ }^{2}$ This action by the President prompted Senators Tom Harkin, Edward M. Kennedy, and Timothy E. Wirth-the three Senators who had requested the safety assessmentto ask for its reevaluation by the author. A copy of this request, which came in the form of a letter dated October 15, 1991, to Director John Nuckolls of the Lawrence Livermore National Laboratory, is provided in Appendix A.

In particular, the Senators' letter requested a reevaluation of the author's estimate that 10 to 20 nuclear explosive tests would be required to incorporate modern safety features into the warheads for the Minuteman III, Trident C4, and Trident D5 missiles, and how many explosive tests could be eliminated if the Navy decided not to incorporate insensitive high explosive (IHE) in the W76/C4 and W88/D5 warheads. The letter also asked for an analysis of the extent to which "pit reuse" for further production of the W88/D5 warhead would require underground testing.

Before attempting to answer the Senators' questions, it will be instructive to list and annotate those provisions of the Bush initiative, as set forth in Defense Secretary Cheney's September 28, 1991 Order, Reducing the United States Nuclear Arsenal, and then to discuss briefly the implications for nuclear weapon safety of that initiative. 


\title{
Defense Secretary Cheney's Nuclear Arsenal Reduction Order of September 28, $1991^{3}$
}

\author{
1. The United States armed forces shall eliminate their inventory of ground-launched theater \\ nuclear weapons.
}

The inventory of W33 8-in., W48 155-mm, and W79 8-in. nuclear artillery shells, together with the W70-1,2,3 Lance surface-to-surface short-range tactical missiles, will be placed in secure storage and subsequently destroyed.

2. Tactical nuclear weapons shall be removed from all surface ships, attack submarines, and landbased naval aircraft bases.

All depth/strike bombs and tactical bombs will be taken off ships, and about half will be destroyed once sent home. W80-0 Tomahawk nuclear cruise missiles will be taken off ships and attack submarines and stockpiled for further use. Older nuclear depth bombs for Navy antisubmarine planes will also be eliminated. (The B90 replacement for the Navy's B57-1,2 depth/strike bomb is unfunded.)

3. United States strategic bombers shall stand down from their alert postures, and their nuclear weapons shall be removed and stored in secure areas.

The 40 (approx.) alert bombers, of the 280-plane B52 and B1B strategic bomber force, that are always on 24-hour readiness alert will be taken off alert.

4. The United States intercontinental ballistic missiles scheduled for deactivation under the terms of the Strategic Arms Reduction Treaty shall stand down from alert.

The single-warhead W56-4 Minuteman II ICBMs scheduled to be deactivated under the Start Treaty will be taken off alert immediately. The missiles will be dismantled once the treaty is ratified, probably some time next year, rather than when the full reductions of the pact take place in seven years.

5. Development of the mobile Peacekeeper ICBM rail garrison system and the mobile portions of the small ICBM program shall be terminated.

The mobile portion of the MX missile system will be cancelled. Its missiles, capable of carrying 10 warheads each, will remain in silos rather than be put on rail cars that could be dispersed in a nuclear attack. The mobile portion of the single-warhead Midgetman system-the truck-carried launchers-will also be cancelled.

6. The nuclear short-range attack-missile program (SRAM II) shall be terminated.

Both the SRAM II strategic missile and the SRAM T tactical missile development programs will be cancelled. Development of the W89 warhead for the SRAM II will probably be continued as a possible replacement for the W88 Trident II warhead and/or the W69 SRAM A warhead. Further development of the W91 warhead for the cancelled SRAM T missile is not anticipated.

7. A Unified Command Plan with a United States Strategic Command to which all elements of the U.S. strategic deterrent are to be assigned shall be submitted to me. 


\section{Nuclear Weapons Safety Implications of the Bush Nuclear Weapons Reduction Initiative}

The author pointed out in his July 26, 1991, safety assessment ${ }^{1}$ that a major improvement in nuclear weapons safety would result if:

1. The retirement of those older nuclear weapons that are being retired or are currently scheduled for retirement before the year 2000 were accelerated.

2. U.S. short-range surface-to-surface tactical nuclear weapons were withdrawn from Europe and either safely stored or dismantled.

3. Air transport of nuclear warheads, or their deployment aboard aircraft that are in close proximity to operating runways, being refueled, or starting their engines, were prohibited in peacetime.

All these improvements in nuclear weapons safety except the ban on air transport of nuclear warheads are embodied in President Bush's nuclear weapons reduction initiative. Warhead transport by air could be reasonably terminated after the mandated return of overseas nuclear weapons has been completed and would result in a substantial improvement in nuclear weapon transportation safety.

When the accelerated retirement of older nuclear weapons is completed, the nuclear weapons stockpile, with the exception of the W78 Minuteman III, W76 Trident I,II C4, and W88 Trident II D5 ballistic missiles, will have been brought up to modern standards of nuclear detonation and plutonium dispersal safety. That is, with the three exceptions noted, all weapons remaining in the stockpile will enjoy the safety advantages of both enhanced electrical isolation (EEI) and insensitive high explosive (IHE), in addition to the property of one-point safety (OPS) required of all nuclear weapons. Some warheads that have entered the stockpile more recently will also have the added safety feature of a fire-resistant pit (FRP).

Appendix $\mathrm{B}$ provides a brief description of these important nuclear weapon safety features and characteristics. Table $\mathrm{C} 1$ of Appendix $\mathrm{C}$ provides a list of all nuclear weapons currently in the U.S. stockpile, their stockpile entry date, their comparative safety rating, and their retirement status prior to the Bush initiative of September 27, 1991.

\section{Safety-Related Nuclear Test Requirements}

The number of nuclear explosive tests needed to upgrade the safety of nuclear warheads depends on the means used to accomplish the upgrade and on the availability of the pit production facilities at Rocky Flats* (See Appendix B for a description of a nuclear warhead 'pit.') If these facilities at Rocky Flats remain unavailable, any further warhead production must use existing pits salvaged from warheads that are being retired.

The estimated number of nuclear tests needed to accomplish a variety of specified warhead safety upgrades and other stockpile actions is listed in Table 1. The number of tests listed assumes that testing is minimized and that no unexpected difficulties are encountered. The smaller number of tests (in brackets at right) applies if Rocky Flats resumes operation, in which case salvaged pits need not be used.

\footnotetext{
* In November 1989, the DOE announced a shutdown of plutonium processing at its Rocky Flats plant near Denver, Colorado. Efforts to clean up the plant have been underway since, but no date has been set for resuming operations.
} 
Table 1. Estimate of the number and kinds of nuclear tests required to accomplish various warhead safety upgrades and other stockpile actions. (Symbol key: $\mathrm{p}=$ production verification test, $\mathrm{s}=$ salvaged-pit performance test, $\mathrm{e}=$ different environment and/or packaging test, $\mathrm{f}=$ enhanced fire-safety test, and $\mathrm{d}=$ newwarhead development test.)

$\begin{array}{cc}\text { Actions taken } & \begin{array}{c}\text { Number and kinds } \\ \text { of tests needed }\end{array}\end{array}$
(A) Resume production of the W88 Mk5
Trident II warhead

(B) Replace the W88 Mk5 warheads with W89 Mk5 warheads

(C) Resume production of the $\mathrm{W} 87 \mathrm{Mk} 21$ MX warhead

(D) Modify the W87 Mk21 warhead for use on the SICBM

(E) Same as (D), but including enhanced fire safety

(F) Replace the W78 Mk12A Minuteman III warheads with W87 Mk21 warheads ${ }^{b}$

(G) Retrofit the W69 SRAM A with with W89-Alt warheads:

(H) Develop a new warhead incorporating IHE to replace the W88 warhead

(I) Develop a new warhead incorporating IHE to replace the W76 warhead

$$
(2 ; \mathrm{p}+\mathrm{s}) ?^{\mathrm{a}} \quad[1 ; \mathrm{p}]
$$

$3 ; p+s+e \quad[2 ; p+e]$

$2 ; p+s \quad[1 ; p]$

3; $p+s+e \quad[2 ; p+e]$

$4 ; \mathrm{p}+\mathrm{s}+\mathrm{e}+\mathrm{f} \quad[3 ; \mathrm{p}+\mathrm{e}+\mathrm{f}]$

3; $p+s+e \quad[2 ; p+e]$

$3^{c} ; p+2 e \quad[2 ; p+e]$

$4 ; p+3 d \quad[4 ; p+3 d]$

$4 ; p+3 d \quad[4 ; p+3 d]$

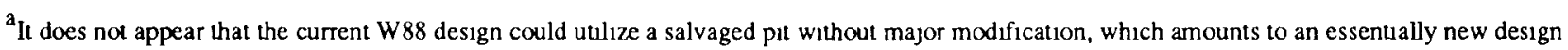
(See $\mathrm{H}$ below)

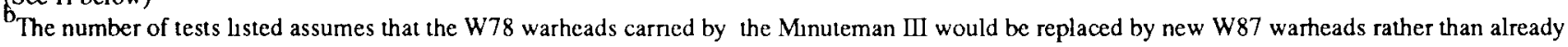
existing ones In the latter circumstance, a production verification test and salvaged-pit test would not be necessary, and the number of tests needed would be reduced to $1,[1]$

${ }^{c}$ One performance test with a salvaged pit has already been carried out successfully

Assuming the W87 warhead were used to replace (safety upgrade) the W78 Minuteman warhead and no further W76 or W88 warheads were produced, the number of tests required would be (see Action F):

3, [2].

If production of the W88 warhead is to be resumed, which may necessitate that Rocky Flats be operating, a production verification test would be required (see Action $A$ ), bringing the total number of tests to:

$[3](=[2]+[1])$.

In either case, a reasonable estimate of the of the number of nuclear tests required, allowing one test for contingencies, is:

3-4 nuclear tests to upgrade the Minuteman III to an " $A$ " safety rating 
Note, however, President Bush's statement in his September 27, 1991, address that

"The small single-warhead ICBM [SICBM] will be our only remaining ICBM modernization program,"

which would seem to preclude modernizing the Minuteman III ICBM to upgrade its safety. If this interpretation is correct, the Minuteman missiles would continue to be deployed as is, in decreasing numbers (because some are retired), and no nuclear tests related to the Minutman III would be necessary.

A minimum of 3,[2] nuclear tests (see Action $B$ ) will be needed if, in addition to upgrading the Minuteman III to an " $\mathrm{A}$ " safety rating, it is desired to upgrade the W88 to an " $\mathrm{A}$ " safety rating as well. Adding these tests to those needed for the Minuteman upgrade (Action F) brings the minimum total number of tests needed to

$6(=3+3),[4](=[2]+[2])$.

If two tests are added for contingencies, the estimated requirement becomes:

6-8 nuclear tests to upgrade both the Minuteman III and the Trident II to an "A" safety rating.

Incorporating IHE into the Navy's W76 Mk4 warhead to upgrade its safety is problematical if Rocky Flats is not in operation. If Rocky Flats is in operation, the W76 could be replaced with a new design that incorporates both IHE and a FRP. The minimum number of tests required in this case would be [4] (see Action I). If one test is added for contingencies and Rocky Flats is assumed to be operating, the estimated requirement becomes:

11-13 nuclear tests to upgrade the Minuteman III, Trident I,II (C4), and Trident II (D5) warheads to an " $\mathrm{A}$ " safety rating

If Rocky Flats is not operating, the safety of the W76 Trident I,II C4 could still be improved somewhat by changing its design to accomodate four missiles instead of eight and replacing, with suitably designed blast/debris deflectors and barriers, the four alternate missile stations that would be removed. This would effectively isolate the four remaining warheads from each other so that accidental detonation of the high explosive of any one of them would not cause detonation of the others.

Further safety improvement would result if the detonatable third-stage propellant of the missile were replaced with a nondetonatable propellant so that detonation could not be propagated from one warhead to another via detonation of the intervening propellent. Such a safety upgrade would require one nuclear test at most and more probably would require none.

\section{Summary and Conclusions}

The principal effect of the Bush initiative, with respect to the safety of the U.S. nuclear weapons stockpile, will be to accelerate the retirement of older nuclear weapons that lack modern safety features. Operational safety will also be improved by removing them from aircraft and surface ships and returning them to secure storage. Once these weapons have been returned to storage, transportation safety could be improved significantly by eliminating the transport of nuclear weapons by air.

When the accelerated retirement of older nuclear weapons is complete, the nuclear weapons stockpile, save for the W78 Minuteman III, W76 Trident I,II C4, and W88 Trident II D5 ballistic missiles, will be up to modern standards of nuclear detonation and plutonium dispersal safety. That is, with the three exceptions noted, all weapons remaining in the stockpile will enjoy the modern safety advantages of both EEI and IHE in addition to the property of one-point detonation safety required of all nuclear weapons. Some warheads that have entered the stockpile more recently will also have the added safety feature of a FRP.

It is estimated that 6-8 nuclear explosive tests will be required to replace the Minuteman III and Trident II D5 missile warheads with warheads incorporating IHE and FRPs. If only the Minuteman III is to be given 
this safety upgrade, half as many (3-4) tests, will be needed. In each case, the larger number of tests would apply if the plutonium processing facilities at Rocky Flats remain shut down, necessitating the reuse of old plutonium pits salvaged from retired warheads rather than the use of freshly manufactured pits.

Incorporating IHE into the older W76 Trident I,II C4 missile warhead is problematical if Rocky Flats remains unavailable. The same is true of the W88 warhead. In the latter case, however, the W88 can be replaced by the W89, which has all the modern safety features and can be manufactured with salvaged pits should Rocky Flats remain closed.

If Rocky Flats resumes operation, the W76 could be replaced by a new design that incorporates both IHE and a FRP, requiring an estimated 5 nuclear tests. The safety upgrade of all three U.S. ballistic missiles would then call for a total of 11-13 nuclear tests. This more-refined estimate of the number of nuclear tests needed to bring the stockpile up to modern standards of safety is bracketed by our earlier estimate of $10-20$ tests, ${ }^{1}$ but lies considerably closer to 10 than to 20 .

In conclusion, the answers to the three questions posed in the Senators' letter are:

1. It is estimated that 11-13 nuclear tests would still be required to add IHE to those ballistic missiles not scheduled for retirement, namely the Minuteman III, C4, and D5 missiles.

2. A total of 3-4 nuclear tests would be required for the Minuteman III upgrade alone.

3. Pit reuse is probably not a feasible option for further production of the W88 warhead. If Rocky Flats resumes operation, further production of unmodified W88 warheads would require only 1 nuclear test to verify performance. A total of 3-4 tests would be required if the W88 is to be replaced by the W89; the smaller number would apply if Rocky Flats were operating. (Production of a new design incorporating IHE would be expected to require 5 nuclear tests.)

\section{References}

1. R.E. Kidder, Report to Congress: Assessment of the Safety of U.S. Nuclear Weapons and Related Nuclear Test Requirements, Lawrence Livermorc National Laboratory, Livermore, CA, UCRL-LR-107454 (1991).

2. "Text of Remarks by the President," The New York Times (National Edition), September 28, 1991, p. 4.

3. "Order sent by Defense Secretary Dick Cheney," The New York Times (National Edition), September 29, 1991, p. 8. 


\section{List of Abbreviations Used}

$\begin{array}{ll}\text { ABM } & \text { Antiballistic missile } \\ \text { AFAP } & \text { Artillery-fired atomic projectile } \\ \text { ALCM } & \text { Air-launched cruise missile } \\ \text { CPU } & \text { Central processing unit } \\ \text { DOD } & \text { Department of Defense } \\ \text { DOE } & \text { Department of Energy } \\ \text { EEI } & \text { Enhanced electrical safety } \\ \text { ENDS } & \text { Enhanced nuclear detonation safety } \\ \text { FRP } & \text { Fire-resistant pit } \\ \text { GLCM } & \text { Ground-launched cruise missile } \\ \text { HE } & \text { High explosive (conventional) } \\ \text { ICBM } & \text { Intercontinental ballistic missile } \\ \text { IHE } & \text { Insensitive high explosive } \\ \text { IRBM } & \text { Intermediate-range ballistic missile } \\ \text { LLNL } & \text { Lawrence Livermore National Laboratory } \\ \text { MS } & \text { Mechanical safing } \\ \text { NDSB } & \text { Nuclear depth/strike bomb } \\ \text { OPS } & \text { One-point safety } \\ \text { RB } & \text { Reentry body } \\ \text { SC } & \text { Separable components } \\ \text { SICBM } & \text { Small (single-warhead) ICBM } \\ \text { SLBM } & \text { Submarine-launched ballistic missile } \\ \text { SLCM } & \text { Sea-launched cruise missile } \\ \text { SRAM } & \text { Short-range attack missile } \\ \text { SSTM } & \text { Surface-to-surface tactical missile }\end{array}$



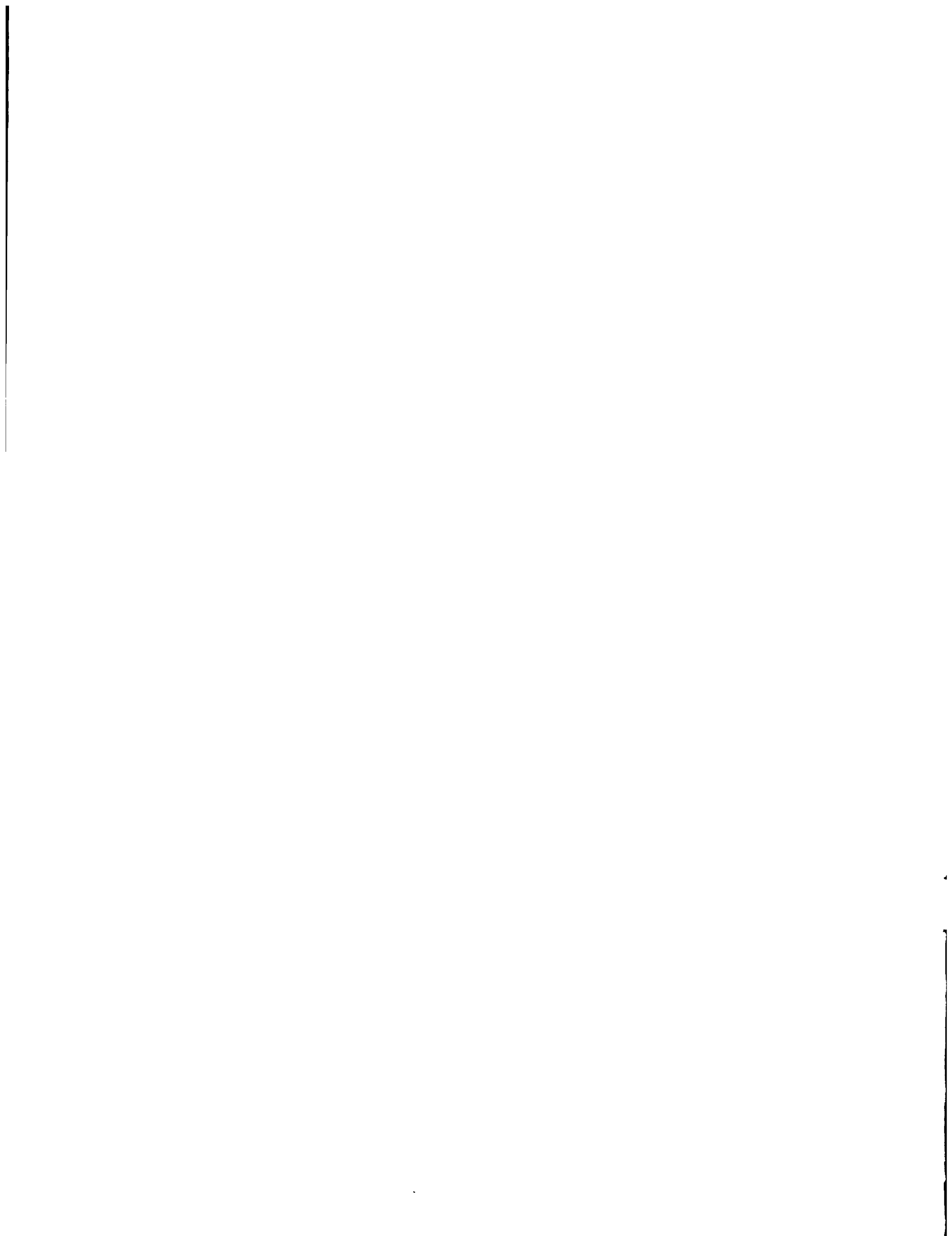
$+2$ 


\title{
Appendix A
}

\section{Letter from Tom Harkin to John Nuckolls}

\section{qunited States Semate}

\author{
WASHINGTON DC 20510
}

October 15, 1991

Dr. Johs Nuckolls, Director

Lawrence Livermore National Laboratory

P.O. EOX 808

Livermore, California 94550

Dear Dr. Nuckolls:

As you know, Dr. Kay kldder has provided Congress with several studies related to the reliablity and satety of our nuclear weapons arsenal. His reports have beer useful as we consider the need for additional nuclear weapons tests. In his latest analysis, he estimated that 10 to 20 more nuclear explosions would be adequate to incorporate modern sarety features into the warheads for the Minuteman-III, C-4 and D-5 missiles.

We respectfully request that you ask Dr. kidder to reevaluate his safety analysis in view of Fresident Bush's recent initiative to remove all ground-based tactical nuclear weapons, raval nuclear weapons, and to remove nuclear weapons from bombers on alert. Without bombers on alert, ano with the removal of the nldest tactical nuclear weapons, do we still need 10 to 20 more nuclear explosions to add insensitive high explosive (IHE) to the olcer strategic warheads?

Furthermore, if the Navy decices not to incorporate IHE in the $w-76$ and $w-88$ warheads, how many explosive tests would be reguired for the Minuteman-III warnead upgrade? Finaliy, we woula appreciate Dr. Kidder's analysis of the extent to which "pit reuse' for further production of the $w-88$ warhead would reguire unatrground testing.

This request is not intended to initiate a completely new report by Dr. Kidder. Instead, we are seeking only an update of his earlier report in view of the latest developments. We hop that this would minimize the resources reguled

Thank you for corsidering this request.

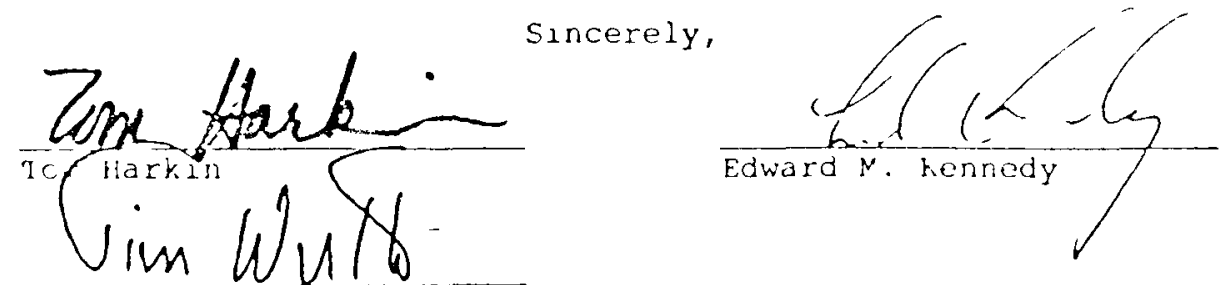

Tinothy E. Wirth 



\section{Appendix B}

\section{Principal Means of Providing Nuclear Warhead Safety}

The principal means of providing for nuclear warhead safety are

1 Enhanced electrical isolation (EEI)-Reduces the probability that the warhead's detonators will be electrically fired in a accident to less than one chance in a million It was first introduced in the B61-5 Tactical Bomb in 1977 [This safety feature is also referred to as Enhanced Nuclear Detonation Safety (ENDS)]

2 Insensitive high explosive (IHE) - A high explosive that is much less sensitive to being detonated by fire or impact than is the HE used in all nuclear warheads that entered the stockpile prior to 1978

3 A fire-resistant pit (FRP) - The pit of a nuclear weapon is that part of the primary, or first stage of the weapon, that contains the plutonium If the plutonium is encased within a ductile, high melting-point metal shell that can withstand prolonged exposure to a jet fuel fire $\left(\sim 1000^{\circ} \mathrm{C}\right)$ without melting or being caten through by the corrosive action of molten plutonium, it qualifies as a FRP The plutonium itself may melt, but will remain contained within the encasing shell and not be dispersed into the environment

4 Mechanical safing (MS) - Can virtually elıminate the possibility that any significant nuclear yield will result from an accident in which the warhead's high explosive (HE) is detonated (A nuclear yield is here defined as significant if it exceeds that equivalent to exploding four pounds of HE ) Mechanical safing has been in successful use for more than 20 years

5 Separable components (SC) - A means of achieving many-point safety by physically separating the plutonium in the warhead from the HE by a sufficient distance and/or barrier before arming the weapon Then accidental detonation of the HE could not result in either plutonium dispersal or nuclear yicld (No warhead in stockpile utilizes this concept)

6 A one-point-safe (OPS) design-Insures no significant nuclear yıeld will result if the warhead's $\mathrm{HE}$ is detonated at any one point

\section{One-Point Safety}

In 1968, a quantitatıve safety requirement was established that all nuclear warheads in the stockple be "one-point safe," which means that if the high explosive in the warhead is detonated at any single point, there will be less than one chance in a million that any significant nuclear yield will result (specifically, no more nuclear yield will result than that equivalent to exploding four pounds of high explosive)

Nuclear warheads in the stockpile are also required to be inherently one-point safe, that is, one-point safety shall be obtained without the use of a nuclear safing device (such as mechanical safing) This should not be interpreted as prohibiting the use of a mechanical safing device, but rather as a requirement that one-point safety should obtain even in its absence

Many-point detonation safety of a sealed-pit warhead can, strictly speaking, only be obtained by means of mechanical safing (In the absence of mechanical safing, a large nuclear yield will surely result if nearsimultaneous detonations should accidentally occur at or near the warhead's detonators ) Indeed, it is possible that an inherently one-point safe warhead, without mechanical safing, could be less safe than a mechanically-safed warhead that was not inherently safe 


\section{Nuclear Safety}

A warhead has the property of nuclear safety or of being nuclear safe, to the degree to which no accidental release of a significant amount of nuclear explosive energy, or nuclear yield, is possible.

EEI and IHE reduce the risk that a warhead's HE will be detonated accidentally-the former electrically, and the latter mechanically. Therefore, each contributes to both nuclear safety and plutonium-dispersal safety (see below).

MS and OPS contribute to nuclear safety but not to plutonium-dispersal safety because neither reduces the risk that a warhead's HE will be detonated accidentally. MS provides both many-point and one-point safety.

\section{Plutonium-Dispersal Safety}

FRP contributes to plutonium-dispersal safety in those accidents in which a warhead is subjected to fire, but only if the warhead's HE does not detonate.

The areal extent of possible plutonium dispersal that can result from a fire in which the HE detonates is far larger-typically 100 times larger-than if it does not. Detonation of the HE causes most of the plutonium to be aerosolized into small micron-sized particles of plutonium oxide that can be carried aloft and dispersed by local winds over a large area. Therefore, EEI and IHE are far more significant contributors to plutoniumdispersal safety than are FRPS. 


\section{Appendix C}

\section{Comparative Safety of U.S. Nuclear Warheads}

Table C1. Warhead safety ratings

\begin{tabular}{|c|c|c|c|}
\hline Warhead & $\begin{array}{l}\text { Weapon } \\
\text { system }\end{array}$ & $\begin{array}{l}\text { Stockpile } \\
\text { entry date }\end{array}$ & $\begin{array}{l}\text { Safety } \\
\text { grade }\end{array}$ \\
\hline \multicolumn{4}{|c|}{ Development } \\
\hline W91 & $\begin{array}{l}\text { SRAM T (missile cancelled and } \\
\text { further warhead development } \\
\text { halted) }\end{array}$ & $\longrightarrow$ & A \\
\hline B90 & $\begin{array}{l}\text { Tactical bomb, NDSB (warhead } \\
\text { unfunded) }\end{array}$ & - & A \\
\hline W89 & SRAM II (missile cancelled) & - & A \\
\hline W61 & Earth penetrator & - & B \\
\hline B61-8 & Tactical bomb & - & B \\
\hline B61-9 & Tactical bomb & - & B \\
\hline B61-6 & Tactical bomb & - & B \\
\hline
\end{tabular}

Stockpile

(Entered stockpile after 1979)

$\begin{array}{lllll}\text { B61-10 } & \text { Tactical bomb } & 1990 & \text { B } & \\ \text { W88 } & \text { Trident II D5 SLBM } & \mathbf{1 9 9 0} & \text { C } & \\ \text { B53-1 } & \text { Strategic bomb } & 1988 & \text { C- } & \text { R } \\ \text { W87 } & \text { MX Peacekeeper ICBM } & 1986 & \text { A } & \\ \text { B61-7 } & \text { Strategic bomb } & 1986 & \text { B } & \\ \text { W80-0 } & \text { Cruise missile, SLCM } & 1984 & \text { B } & \\ \text { B28-0,1 } & \text { Strategic bomb } & 1983 & \text { C- } & \text { R } \\ \text { W84 } & \text { Cruise missile GLCM } & 1983 & \text { A } & \text { R } \\ \text { B83 } & \text { Strategic bomb } & 1983 & \text { A } & \\ \text { W85 } & \text { Pershing II IRBM } & 1983 & \text { B } & \text { R } \\ \text { W80-1 } & \text { Cruise missile, ALCM } & 1982 & \text { B } & \\ \text { W70-3 } & \text { Lance SSTM } & 1981 & \text { D } & \text { BI } \\ \text { W79 } & \text { Artillery shell, 8-inch } & 1980 & \text { C+ } & \text { BI } \\ \text { B61-3 } & \text { Tactical bomb } & 1980 & \text { B } & \\ \text { B61-4 } & \text { Tactical bomb } & 1980 & \text { B } & \\ \text { W78 } & \text { Minuteman III ICBM } & \mathbf{1 9 8 0} & \text { C } & \\ \text { W76 } & \text { Trident I, II C4 SLBM } & \mathbf{1 9 7 9} & \text { C } & \end{array}$

(Entered Stockpile Before 1979)

$\begin{array}{ll}\text { B61-5 } & \text { Tactical bomb }(=>\text { B61-8) } \\ \text { B61-2 } & \text { Tactical bomb }(=>\text { B61-8) } \\ \text { W71 } & \text { Spartan ABM } \\ \text { W70-1,2 } & \text { Lance SSTM } \\ \text { W69 } & \text { SRAM A }\end{array}$

1977

1976

1975

1973

1972

$\begin{array}{lr}\text { C } & \text { R } \\ \text { D } & \text { R } \\ \text { D } & \text { R } \\ \text { D } & \text { BI } \\ \text { D } & \text { R }\end{array}$


Table C1. Warhead safety ratings (continued)

\begin{tabular}{llcll}
\hline Warhead & \multicolumn{1}{c}{$\begin{array}{c}\text { Weapon } \\
\text { system }\end{array}$} & $\begin{array}{c}\text { Stockpile } \\
\text { entry date }\end{array}$ & $\begin{array}{l}\text { Safety } \\
\text { 8rade }\end{array}$ \\
\hline W68 & Poseidon SLBM & 1970 & D & R \\
W62 & Minuteman III ICBM & 1970 & D & R \\
W56-4 & Minuteman II ICBM & 1968 & C+ & R \\
B61-0 & Tactical bomb (=> B61-6,9) & 1968 & D & R \\
B57-1,2 & Depth/strike bomb & 1963 & D & R \\
W48 & Artillery shell, 155mm & 1963 & D & BI \\
W50 & Pershing 1A IRBM & 1963 & D & R \\
B43 & Tactical bomb & 1961 & D & R \\
W33 & Artillery shell, 8-in. & 1956 & NA & BI \\
\hline
\end{tabular}

The letter " $\mathrm{R}$ " in Table $\mathrm{C} 1$ indicates warheads that have been retired or are being retired. The letters "BI" indicate tactical surface-to-surface weapons scheduled for destruction as a result of the Bush initiative. (The symbol => means "to be replaced by.")

The grading system used in Table 1 is as follows:
A: Has EEI, IHE, and FRP.
B: Has EEI, and IHE.
C+: Has improved safety.
C: Has EEI.
C-: Does not have full EEI.
D: Has none of the above safety features.
NA: Not applicable. The W33 does not contain plutonium and is not a sealed-pit design. It is a two-component, gun-assembled weapon that fully satisfies modern safety require- ments when the two components are stored separately.




\section{Appendix D}

\section{Biography}

Dr.Ray E. Kidder, a Fellow of the American Physical Society, has been a senior physicist at the Lawrence Livermore National Laboratory for 35 years. He has written more than 100 classified reports dealing with the physics, properties, design, and effects of nuclear weapons, especially thermonuclear physics and enhanced radiation weapons.

As co-chairman of the "Premortem Committee," he reviewed and evaluated designs of the nuclear warheads and bombs fielded by LLNL prior to testing in Operation Dominic, the last U.S. nuclear test series in the Pacific.

Kidder is also the author of physical models and numerical methods in the fields of thermonuclear physics and magnetohydrodynamics, which have been widely used within the nuclear weapons program. He has contributed to the theory of operation and the design of high-explosive generators of electricity. Further, he directed the Inertial Confinement Fusion program at LLNL for the first 10 years of its existence. He also independently discovered, and recommended to the Atomic Energy Commission, the Atomic Vapor Laser Isotope Separation process that LLNL has subsequently pursued successfully.

More recently, Kidder has been studying the design and application of low-yield nuclear explosives, the design of a reusable underground high-energy-density facility capable of safely containing low-yield nuclear tests, and the properties of nuclear directed-energy weapons.

Kidder is an Alexander von Humboldt Award winner, was for 10 years vice-chairman of the Scientific Advisory Board of the Max-Planck Institute of Quantum Optics, Federal Republic of Germany, and is a past member of the Editorial Board of Nuclear Fusion, the scientific journal of the International Atomic Energy Agency. 
Technical Information Department - Lawrence Livermore National Laboratory University of California • Livermore, California 94551 